\title{
QUALITY ASSURANCE \\ KOMPETENSI APARATUR PENGELOLA KEUANGAN DESA DALAM IMPLEMENTASI KEBIJAKAN DANA DESA
}

\author{
Halim ${ }^{1}$ dan Frida Chairunisa ${ }^{2}$ \\ ${ }^{1}$ Sekolah Tinggi Ilmu Administrasi-Lembaga Administrasi Negara, Makassar \\ ${ }^{2}$ Sekolah Tinggi Ilmu Administrasi-Lembaga Administrasi Negara, Makassar.
}

\begin{abstract}
Abstrak
Dalam rangka mempercepat peningkatan pelaksanaan pembangunan dan kesejahteraan masyarakat di desa, pemerintah pusat merencanakan menyalurkan Dana Desa dalam jumlah besar (Rp.1,4 Milyar) bagi tiap desa. Namun demikian, kemampuan aparat desa dalam pengelolaan Dana Desa sangat mengkhawatirkan mengingat kebanyakan kepala desa hanya berpendidikan SLTA dan SLTP atau sederajat. Selain itu, kondisi kualitas sumber daya manusia perangkat desa yang juga cenderung belum memadai. Banyak penyelewengan yang terjadi dalam pengelolaan dana desa ternyata salah satu penyebabnya adalah rendahnya kualitas sumber daya manusia pengelola dana desa. Oleh karena itu, pemerintah perlu memastikan adanya jaminan kualitas kompetensi aparatur pengelola keuangan desa ketika akan mengucurkan dana desa.
\end{abstract}

Kata Kunci: kebijakan dana desa, kompetensi aparat desa, quality assurance.

\begin{abstract}
In order to accelerate village development and public welfare, central government is committed to disburse village fund in an unprecedented amount (IDR 1.5 million) for each village. However, village officer competence in financial management of the fund is questionable, given the fact that head of village mostly holds junior or senior high school qualifications. Furthermore, in general village officer competence are lacking. Of the many cases of village fund mismanagement, one of the primary causes is the incompetency among village officers. Therefore, it is important for the government to ensure that a quality assurance for officers competence is in place before disbursing the village funds.
\end{abstract}

Keywords: policy of village fund, competency level of village officers, quality assurance.

\section{A. Pendahuluan}

Undang-Undang Nomor 6 tahun 2014 tentang Desa dalam Pasal 72 ayat (1) huruf b dan ayat (2) telah mengamanatkan bahwa salah satu sumber pendapatan Desa berasal dari alokasi Anggaran Pendapatan dan Belanja Negara. Selanjutnya Peraturan Pemerintah Nomor 60 tahun 2014 tentang Dana Desa yang Bersumber dari APBN menegaskan bahwa sumber pendapatan
Desa yang berasal dari alokasi Anggaran Pendapatan dan Belanja Negara tersebut adalah Dana Desa dan Dana tersebut dikelola secara tertib, taat pada ketentuan peraturan perundang-undangan, efisien, ekonomis, efektif, transparan, dan serta bertanggungjawab dengan memperhatikan rasa keadilan dan kepatutan serta mengutamakan kepentingan masyarakat setempat. 
Menurut Menteri Dalam Negeri, dengan Dana transfer (dari APBN) jumlahnya Rp.59,2 triliun, Desa yang berjumlah sekitar 73.000 diperkirakan akan memperoleh anggaran berkisar Rp.800 juta hingga Rp.1,4 miliar per desa. Pengucuran anggaran akan berbeda-beda untuk setiap desa, karena disesuaikan dengan luas desa, jumlah penduduk dan tingkat kebutuhan hidup di desa tersebut (jpnn.com, 13 Maret 2014). Apabila dikelola dengan benar, Dana Desa akan mempercepat peningkatan pembangunan dan kesejahteraan desa. Dan akan berimplikasi pada pembangunan kabupaten/kota, provinsi, dan Indonesia secara keseluruhan.

Namun demikian, Dana Desa juga dapat berimplikasi negatif dengan berujung pada banyaknya aparatur desa yang terkena kasus hukum apabila tidak dikelola dengan benar, antara lain Presiden RI, Wakil Ketua DPR RI, Bupati Wakatobi, Anggota DPRD Sulawesi Tenggara, Kepala BPK RI Perwakilan Jawa Barat, dan Akademisi Universitas Hasanuddin mengkhawatirkan kemampuan aparat desa dalam pengelolaan Dana Desa, mengingat kebanyakan kepala desa hanya berpendidikan SLTA dan SLTP atau sederajat. Selain itu, kondisi kualitas sumber daya manusia perangkat desa yang memang cenderung belum memadai (YIPD, 24 Maret 2014).

Sejalan dengan itu, hasil kajian Komisi Pemberantasan Korupsi dengan halnya pengelolaan dana desa, sebagaimana yang dinyatakan oleh Wakil Ketua KPK Laode M Syarif pada tanggal 2 Agustus 2017 menunjukkan bahwa terdapat kelemahan dalam empat aspek dalam pengelolaan dana desa, yaitu dari segi regulasi, tata laksana, pengawasan, dan kualitas sumber daya manusia sebagai pengelola dana desa (detiknews.com, 2 Agustus 2017).

Dengan demikian, tidak dapat dipungkiri bahwa kualitas sumber daya manusia yang mengurusi dana desa merupakan salah satu aspek esensial yang perlu segera ditangani. Sumber daya manusia yang tidak kompeten, tentu akan semakin memperbesar peluang terjadinya penyimpangan dalam pengelolaan dana desa. Beberapa berita pada media massa mengungkapkan permasalahan dan urgensi hal tersebut.

Di daerah Sulawesi Selatan, telah terbukti terjadinya penyimpangan dana desa. Beberapa kasus korupsi dana desa mengemuka dalam beberapa waktu terakhir ini. Penyelewengan dana desa sepanjang tahun 2016 sampai dengan 2017 terungkap berupa temuan 110 kasus korupsi dana desa dengan pelaku sebagian besar adalah Kepala Desa. Misalnya, kasus yang terjadi di Desa Komba Kecamatan Larompong Kabupaten Luwu, dimana mantan Kepala Desa dijadikan tersangka tindak pidana korupsi penyalahgunaan Dana Desa Tahun Anggaran 2016 sebesar kurang lebih Rp 289 juta atas dugaan pemalsuan dokumen keuangan desa. Penyalahgunaan dana desa juga terjadi di Desa Taraweang Kecamatan Labakkang Kabupaten Pangkep dengan kerugian negara sebesar Rp 154 juta. Tersangkanya adalah Kepala Desa aktif Taraweang yang diduga melakukan penyelewengan terhadap penggunaan dana desa di bidang pemberdayaan desa dan pembangunan fisik desa diantaranya pembangunan drainase, jembatan kayu, sumur bor dan paving blok (Kareba Desa: Media Berbagi Info dari Desa, 4 Oktober 2017).

Di Yogyakarta, Kejaksaan Negeri (Kejari) Gunungkidul menahan Kepala Desa Bunder, Kecamatan Patuk, Kabul Santosa sebagai tersangka kasus dugaan korupsi Anggaran Belanja dan Pendapatan Desa (ABPDes) Bunder, dengan modus tidak memasukkan dana desa ke kas desa, melainkan memasukkan uang tersebut ke dalam kekayaan pribadinya (Kompas.com, 23 Mei 2017).

Di Lampung Timur, Mantan Kepala Desa Negeri Katon, Kecamatan Marga Tiga, Takim (usia 47 tahun), dituntut pidana penjara selama satu tahun dan enam bulan dengan dakwaan mengerjakan tiga kegiatan yang bersumber dari dana desa Negeri Katon tahun anggaran 2015 sebesar 
Rp 443 juta. Tiga kegiatan itu berupa pembangunan dua belas gorong-gorong, pembangunan jalan onderlagh sepanjang 2.250 meter, dan pembuatan satu unit sumur bor (Tribunnews.com, 12 Juni 2017).

Dengan demikian, jika permasalahan kualitas kompetensi aparat di desa dalam mengelola Dana Desa tidak cepat dicarikan solusinya maka pemerintah pusat akan mengalami kesulitan dalam meningkatkan kesejahteraan masyarakat di pedesaan dikarenakan banyaknya aparatur desa yang akan terjerat tindak pidana hukum karena melakukan penyimpangan yang disebabkan ketidakmampuan mengelola sesuai dengan ketentuan peraturan perundang-undangan.

\section{B. Kerangka Pikir Quality Assurance Kompetensi Aparatur Pengelola Dana Desa}

Quality Assurance Kompetensi Aparatur Pengelola Dana Desa dalam kajian ini didasarkan pada tiga konsep dasar quality assurance kompetensi aparatur yang akan sangat mempengaruhi proses dalam tata kelola dana desa di Indonesia pada saat ini.

Pertama, pengelolaan Dana Desa telah diatur dalam Undang-Undang Nomor 6 tahun 2014 tentang Desa, Peraturan Pemerintah Nomor 43 tahun 2014 tentang Peraturan Pelaksanaan Undang-Undang Nomor 6 tahun 2014 tentang Desa, dan Peraturan Pemerintah Nomor 60 tahun 2014 tentang Dana Desa yang bersumber dari Anggaran Pendapatan dan Belanja Negara. Di samping itu, diatur secara operasional dalam Peraturan Menteri Dalam Negeri, Menteri Teknis/Pimpinan Lembaga Pemerintah Non Kementerian terkait, Peraturan Bupati/Walikota, dan Peraturan Desa. Dengan demikian, tata cara pengelolaannya telah memiliki standar yang terukur.

Kedua, pengelolaan Dana Desa membutuhkan sumber daya manusia yang mampu mengelola sesuai dengan ketentuan peraturan perundang-undangan. Sementara itu, kompetensi aparat desa cenderung meragukan karena memiliki kualitas yang rendah.

Ketiga, pembangunan dan peningkatan kualitas aparat desa dapat dilakukan dengan cara sertifikasi yang dijamin pemberiannya melalui ujian sertifikasi. Sertifikasi ini sebaiknya didukung pelatihan yang efektif untuk dapat membantu aparat desa dalam memahami, terampil, dan berintegritas dalam mengelola dana desa.

\section{Perspektif Teoritis Quality Assurance Kompetensi Aparatur Pengelola Dana Desa}

Boyatzis (1982) mendefinisikan kompetensi sebagai suatu karakteristik atau kemampuan individu yang memungkinkan mereka menunjukkan tindakan spesifik yang sesuai kebutuhan. Kesenjangan antara kompetensi yang dibutuhkan dengan kompetensi yang tersedia menunjukkan perlunya pengembangan kompetensi.

Ketidakmampuan aparat desa dalam mengelola dana desa dapat berimplikasi terhadap banyaknya aparat desa yang berurusan dengan penegak hukum. Hal ini sejalan dengan pandangan Soekanto (1982) bahwa ketaatan seseorang terwujud melalui pengetahuan, pemahaman, dan sikapnya terhadap hukum. Sejalan dengan itu, menurut Kelman (1966) kualitas ketaatan seseorang sangat ditentukan oleh ketentuan hukum telah terinternalisasi sebagai nilai dalam dirinya, rasa malu terhadap publik, ataupun rasa takut terhadap sanksi. Oleh karena itu, pengetahuan, pemahaman, sikap, dan ketaatan aparat desa terhadap ketentuan mekanisme pengelolaan dana desa merupakan suatu keniscayaan.

Dengan demikian, dibutuhkan "alat" untuk menjamin kualitas kompetensi aparat desa dalam mengelola Dana Desa. Dalam era modern, "alat pengenal" kemampuan seseorang dapat ditunjukkan oleh sertifikat. Pemberian sertifikat dapat digunakan untuk 
memastikan seorang aparat desa telah memiliki kemampuan yang dibutuhkan dalam mengelola dana desa apabila dilakukan melalui ujian kompetensi yang objektif dan efektif.

Sertifikasi komptensi tersebut akan lebih baik jika disertai dengan pelatihan yang efektif. Pemikiran yang dikemukakan Taylor dalam Rahman (2012) menegaskan bahwa sumber daya manusia membutuhkan latihan yang tepat. Teori ini tepat untuk menghindari kemungkinan yang terburuk dalam kemampuan dan tanggungjawab bekerja, sehingga dalam menyelesaikan tugas jabatan lebih efektif dan efisien sesuai dengan aturan yang telah ditetapkan.

\section{Arah Quality Assurance Kompetensi Aparatur Pengelola Dana Desa}

Mencermati kebutuhan terjaminnya kemampuan aparatur pengelola dana desa dalam mengelola dana desa maka arah quality assurance yang diusulkan adalah:

Pertama, dalam hal upaya menjamin kualitas kompetensi aparatur pengelola dana desa sesuai kebutuhan yakni benarbenar mampu mengelola dana desa sesuai ketentuan peraturan perundang-undangan yang berlaku, perlu ditetapkan sertifikasi kompetensi melalui tahap ujian sertifikasi. Sertifikasi kompetensi tidak semata-mata pemberian sertifikat kompetensi saja, tetapi lebih jauh dari itu adalah penjaminan dan pemeliharaan kompetensi kerja. Dengan begitu, pelaksanaan sertifikasi kompetensi harus tunduk pada kaidah-kaidah sistem penjaminan mutu yang berlaku.

Kedua, dalam halnya mendukung pembangunan kompetensi dan kualitas aparat desa dalam pengelolaan dana desa, pemerintah perlu menyiapkan pelatihan yang efektif.

Ketiga, sertifikasi kompetensi akan berkembang apabila ada kejelasan dan kepastian tentang rekognisi dari sertifikasi kompetensi tersebut. Rekognisi sertifikasi merupakan pengakuan pemerintah serta publik atas sertifikat kompetensi dimiliki oleh seseorang.

Keempat, sertifikasi kompetensi wajib dimiliki oleh para aparatur desa untuk meminimalisasi terjadinya penyimpangan dalam pengelolaan dana desa terutama penyimpangan yang misalnya disebabkan oleh ketidaktahuan.

\section{E. Alternatif Kebijakan}

\section{Opsi Ideal}

a. Pemerintah harus memastikan Kepala dan Perangkat Desa sebagai pengelola Dana Desa memiliki kemampuan memadai melalui ujian sertifikasi. Desa yang Kepala Desa dan/atau Perangkat Desanya tidak lulus ujian tidak berhak menerima Dana Desa. Dana desa akan diberikan ketika Kepala Desa dan/atau Perangkat Desanya kemudian lulus ujian pada kesempatan yang akan datang. Kesempatan ujian sertifikasi tidak dibatasi. Pengembangan kompetensi aparat Desa dalam hal pengelolaan keuangan dilakukan melalui serangkaian cara yang sistematis dan terintegrasi misal dengan cara diadakannya diklat, bimtek dan pendampingan di tempat kerja oleh tim khusus yang dibentuk.

b. Pembentukan Tim Pendamping yang dimotori oleh Bappeda didukung instansi lain yang relevan untuk membantu aparat desa melakukan perencanaan, pengelolaan, dan mengawasi pertanggungjawaban dana desa secara terus-menerus dalam setahun.

c. Pengembangan budaya kerja di kalangan aparat desa untuk menjamin keberlanjutan Diklat, Bimtek, dan pendampingan yang telah selesai dilakukan. Pengembangan budaya kerja 
diarahkan pada perwujudan kepemerintahan yang baik.

d. Pembuatan kebijakan yang memberi insentif bagi desa yang berkinerja tinggi dalam pengelolaan dana desa dan sebaliknya sanksi tegas bagi yang melakukan pelanggaran.

e. Pemberian alokasi anggaran secara penuh sesuai amanat Undang-Undang No. 6 tahun 2014 tentang Desa.

\section{Opsi Moderate}

a. Pemerintah mengembangkan kompetensi Kepala Desa beserta Perangkat Desa melalui cara sistematis dan terintegrasi, misalnya: Diklat, Bimtek dan pendampingan di tempat kerja oleh tim khusus yang dibentuk. Selanjutnya dilakukan ujian sertifikasi bagi Kepala Desa dan Aparat Desa. Kepala Desa dan/atau Perangkat Desanya tidak lulus ujian dilakukan pemotongan Dana Desa secara proporsional. Dana desa diberikan utuh apabila Kepala Desa dan/atau Perangkat Desanya telah dinyatakan lulus ujian sertifikasi di kesempatan berikutnya. Kesempatan untuk ujian sertifikasi tidak dibatasi.

b. Pembentukan Tim Pendamping yang dimotori oleh Bappeda didukung oleh Inspektorat, dan Dinas Pengelolaan Keuangan Daerah atau instansi lain yang relevan untuk secara periodik membantu aparat desa dalam melakukan pengelolaan dari perencanaan, pengelolaan serta pertanggungjawaban.

c. Pembuatan kebijakan yang memberi insentif bagi desa yang berkinerja tinggi dalam pengelolaan dana desa dan sebaliknya sanksi tegas bagi yang melakukan pelanggaran. d. Pemberian anggaran dengan besaran secara bertahap menuju alokasi anggaran secara penuh sesuai amanat Undang-Undang Nomor 6 tahun 2014 tentang Desa. Kecepatan mencapai alokasi penuh didasarkan pada kinerja pengelolaan anggaran tahun sebelumnya.

\section{Opsi Soft}

a. Pemerintah melakukan Piloting dengan cara mengembangkan kompetensi Kepala Desa dan Perangkat Desa melalui cara sistematis dan terintegrasi, misalnya: Diklat, Bimtek dan pendampingan di tempat kerja oleh tim khusus dari Bappeda dan Inspektorat. selanjutnya dilakukan ujian sertifikasi bagi Kepala Desa dan Aparat Desa. Jika Kepala Desa dan/atau Perangkat Desanya tidak lulus ujian diberi kesempatan untuk ujian kembali maksimal dua kali. Jika setelah ujian kedua belum lulus maka dilakukan pemotongan Dana Desa secara proporsional. Pada kesempatan untuk ujian sertifikasi setelah dilakukan pemotongan dana desa tidak dibatasi.

b. Pembuatan kebijakan memberi insentif bagi desa yang kinerja tinggi dalam pengelolaan dana desa dan sebaliknya, sanksi tegas bagi yang melakukan pelanggaran.

c. Pemberian anggaran dengan besaran secara bertahap menuju alokasi anggaran secara penuh sesuai amanat Undang-Undang No.6 tahun 2014 tentang Desa. Kecepatan mencapai alokasi penuh tersebut didasarkan pada kinerja pengelolaan anggaran tahun sebelumnya. 


\section{F. Rekomendasi}

Berdasarkan beberapa opsi yang sudah ditawarkan, kami menyarankan agar Pemerintah Pusat, khususnya Kementerian Desa, Pembangunan Daerah Tertinggal, dan Transmigrasi melaksanakan opsi ideal, mengingat dalam pengelolaan dana desa dibutuhkan ketegasan dan kepedulian pemerintah pusat. Apabila dilaksanakan dengan konsisten maka pegawai yang mengelola dana desa akan berupaya keras untuk segera mencapai kualitas kompetensi yang dipersyaratkan untuk dapat menerima dana desa. Namun demikian, tetap terdapat risiko dimana akan terdapat desa-desa yang tidak menerima dana desa karena tidak mampu mencapai kualitas kompetensi yang dipersyaratkan. Namun demikian, sudah merupakan sifat alamiah manusia untuk berupaya maksimal agar dapat lulus. Oleh karena itu, agar opsi ini berhasil diperlukan adanya pengawasan ketat terhadap pihak penyelenggara ujian sertifikasi dalam menerapkan standar ujian sertifikasi.

Adapun opsi moderat tidak kami rekomendasikan, hal itu karena pencapaian kualitas kompetensi pegawai pengelola dana desa akan menjadi lambat, bahkan kemungkinan tidak terjadi peningkatan kualitas kompetensi pengelola dana desa secara signifikan, walaupun kebijakan ini akan disukai oleh banyak kalangan. Di samping itu, dibutuhkan pengawasan ketat terhadap pihak penyelenggara ujian sertifikasi dalam menerapkan standar ujian sertifikasi dan pengawasan ketat terhadap pihak yang berwenang menetapkan porsi pemotongan dana desa.

Demikian pula opsi soft tidak kami rekomendasikan, hal itu karena pencapaian kualitas kompetensi pegawai pengelola dana desa akan sangat lambat, bahkan kemungkinan tidak terjadi peningkatan kualitas kompetensi pengelola dana desa, walaupun kebijakan ini akan disukai oleh sangat banyak kalangan. Di samping itu, dibutuhkan pengawasan ketat terhadap pihak penyelenggara ujian sertifikasi dalam menerapkan standar ujian sertifikasi dan pengawasan ketat terhadap pihak yang berwenang menetapkan porsi pemotongan dana desa.

\section{Daftar Pustaka}

Boyatzis, R. (1982). The Competent Manager: A Model for Effective Performance. New York: John Wiley \& Sons

Kelman, H.C. 1966. Compliance, Identification and Internalization; Three Processes of Attitude Change, dalam H.Proshanky and B.Seideberg (eds). Basic Studies in Studies in Sosial Psychology. New York: Holt, Rhinehart and Winston

Rahman, Md.Hasebur. 2012. Henry Fayol and Frederick Winslow Taylor's Contribution to Management Tought: An Overvieuw, dalam Asian Business Consortium Journal of Advanced Research 1 (2), USA

Soekanto, Soerjono. 1982. Kesadaran Hukum dan Kepatuhan Hukum. Jakarta: Rajawali Press

\section{Peraturan Perundangan}

Undang-Undang Nomor 6 tahun 2014 tentang Desa. 15 Januari 2014. Lembaran Negara Republik Indonesia tahun 2014 Nomor 7. Jakarta.

Peraturan Pemerintah Nomor 43 tahun 2014 tentang Peraturan Pelaksanaan Undang-Undang Nomor 6 tahun 2014 tentang Desa. 30 Mei 2014. Lembaran Negara Republik Indonesia tahun 2014 Nomor 123. Jakarta.

Peraturan Pemerintah Nomor 60 tahun 2014 tentang Dana Desa yang Bersumber dari Anggaran Pendapatan dan Belanja Negara. 21 Juli 2014. Lembaran Negara Republik Indonesia tahun 2014 Nomor 168. Jakarta. 
$\underline{\text { Website }}$

Detiknews.com. KPK Soroti 4 Dana Desa yang Buka Peluang Korupsi. 2 Agustus 2017. https://news.detik.com/berita/d3584184/kpk-soroti-4-kelemahandana-desa-yang-buka-peluang-korupsi, diakses pada tanggal 11 Desember 2017.

JPNN (jawa pos national network). com. Dana Rp. 1 Miliar per Desa Kemungkinan Cair Juni. 13 Maret 2014.

http://www.jpnn.com/read/2014/03/13/ 221858/Dana-Rp-1-Miliar-per-DesaKemungkinan-Cair-Juli-, diakses pada tanggal 11 Oktober 2017.

Kareba Desa: Media Berbagi Info dari Desa. 4 Oktober 2017. Opini: Awas, Penetrasi Gurita Korupsi Dana Desa. http://www.karebadesa.id/2017/10/opi ni-awas-penetrasi-gurita-korupsi.html, diakses pada tanggal 11 Desember 2017.
Kompas.com. Korupsi Dana Desa Rp.137,9 Juta Seorang Kades Ditahan. $23 \quad$ Mei 2017. http://regional.kompas.com/read/2017/ 05/23/11545871/korupsi.dana.desa.rp. 13.9.juta.seorang.kades.ditahan, diakses pada tanggal 11 Desember 2017.

Tribunnews.com. Korupsi Dana Desa, Takim dituntut 18 Bulan Penjara. 12 Juni 2017. http://www.tribunnews.com/regional/2 017/06/12/korupsi-dana-desa-takimdituntut-18-bulan-penjara, diakses pada tanggal 11 Desember 2017.

YIPD (Yayasan Inovasi Pemerintahan Daerah). Potensi Dampak Negatif Undang-Undang Desa. 24 Maret 2014. http://www.yipd.or.id/en/articles/poten si-dampak-negatif-undang-undangdesa, diakses pada tanggal 11 Oktober 2017. 